\title{
The Kurdish Conflict in Turkey: Issues, Parties and Prospects
}

Article in Security Dialogue · December 1997

DOI: $10.1177 / 0967010697028004005$

CITATIONS

25

1 author:

\section{Nimet Beriker}

Peace Research Institute Oslo

25 PUBLICATIONS 98 CITATIONS

SEE PROFILE
READS

1,408 


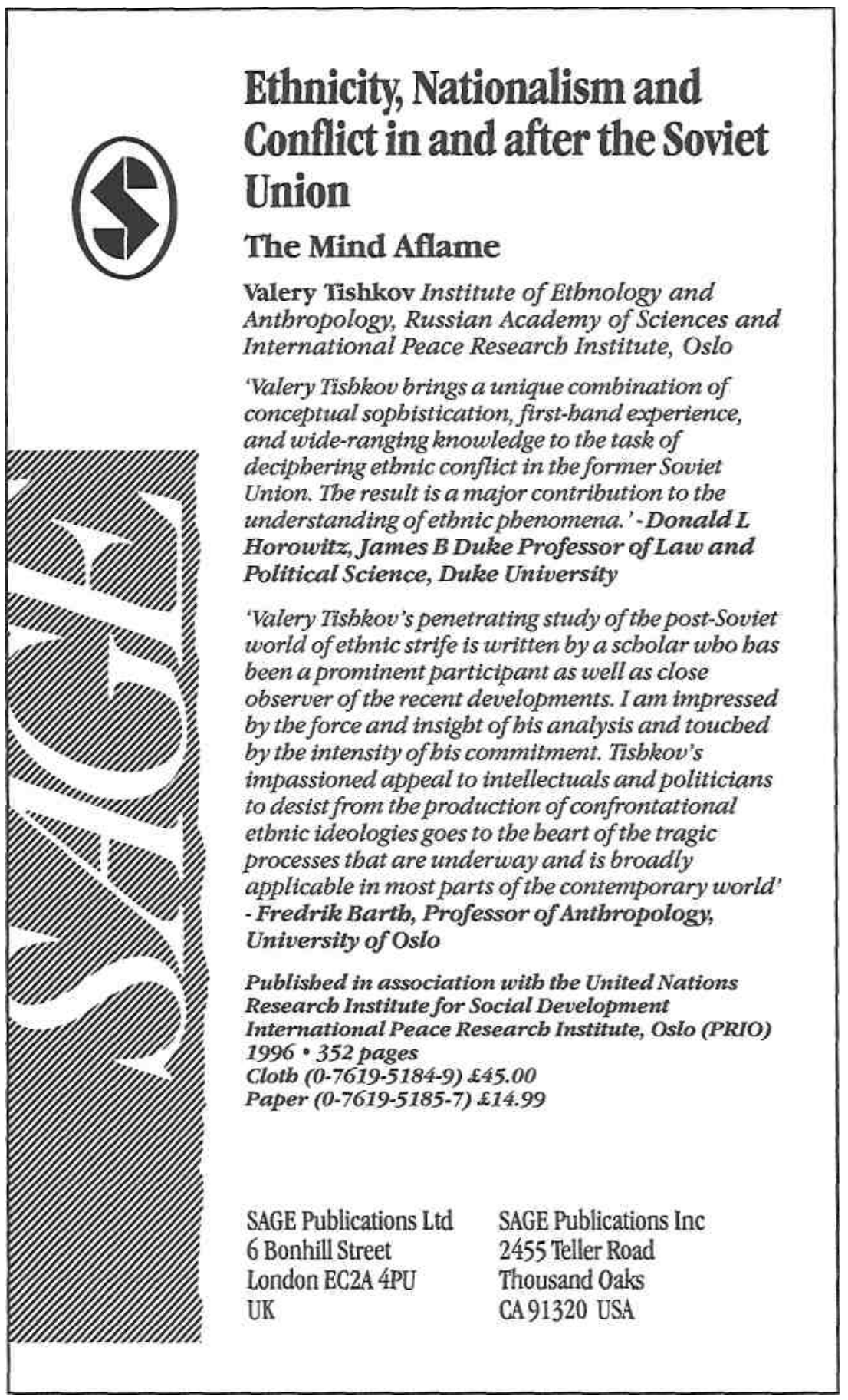




\title{
The Kurdish Conflict in Turkey: Issues, Parties and Prospects
}

\author{
NIMET BERIKER-ATIYAS*
}

Bilkent University, Ankara, Turkey

\section{NATURE AND BACKGROUND OF THE CONFLICT}

$\mathrm{T}$ THE KURDISH CONFLICT in Turkey has been a prolonged affair. The year 1984 marked a new start for the contemporary emergence of the Kurdish problem on the Turkish political agenda. ${ }^{1}$ Since then the conflict has persisted in the form of guerrilla movements and limited warfare between Turkish government forces and the PKK (The Kurdish Workers' Party). The position of the government has been that the preservation of the unity and the territorial integrity of the country cannot be jeopardized. The PKK's declared aims, on the other hand, range from cultural and political rights as an identity group to federalism and separate statehood. ${ }^{2}$

This has been an increasingly costly conflict. It is estimated that since 1984, some 20,000 people have lost their lives. In 3,000 villages, schools are shut, leaving 1.5 million children without education. Around 500 medical care centers are closed. Over 3,000 villages have been evacuated. Three million people have migrated from the region. ${ }^{3}$ The government's annual expenditure on this conflict is estimated to be around USD 8 billion. The PKK's annual budget is around USD 3 billion. ${ }^{4}$ Today the conflict has reached what can only be described as a stalemate. No new attempt - whether made by the government or by the PKK - to change the flow of the events is likely to have a significant impact on the status quo.

As the conflict has unfolded, it has created new actors and issues. Byproducts of the conflict include drug (mostly heroin) trafficking and the emergence of new power-centers in the political system, and the rehabilitation problem of the homecoming soldiers. In November 1996, a political scandal 


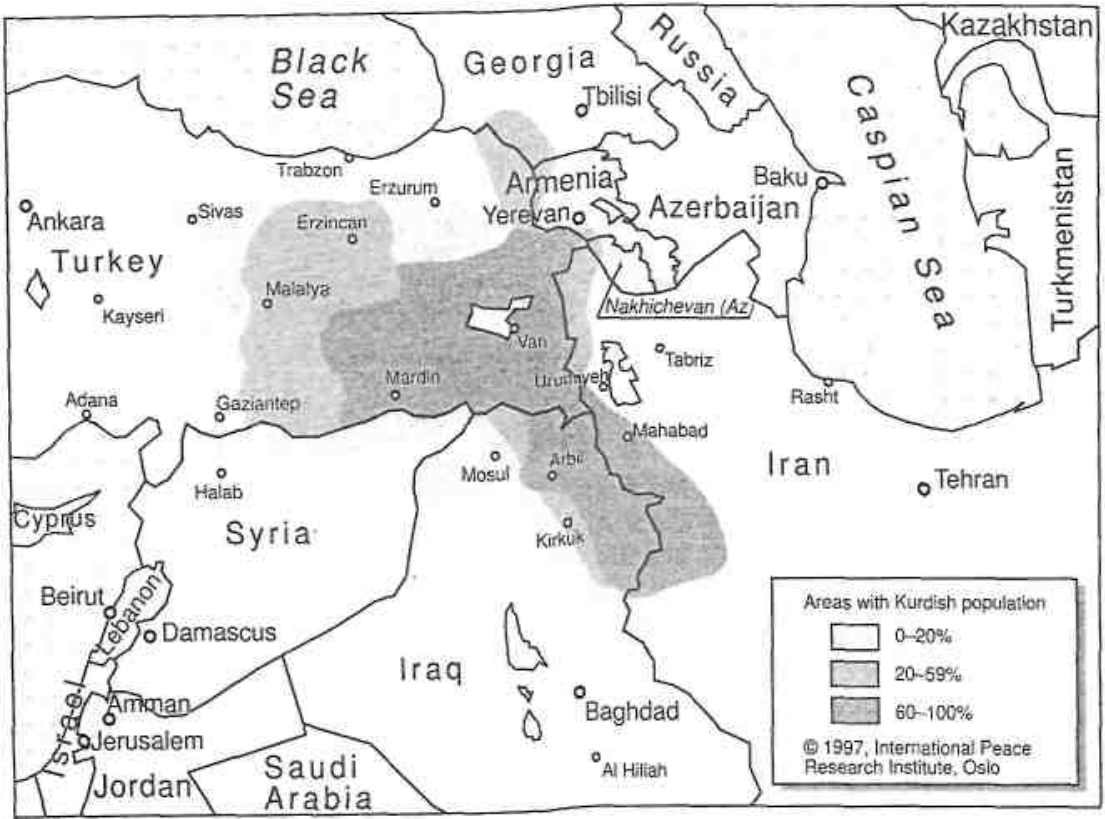

Distribution of Kurds

which resulted in the resignation of the minister of internal affairs exposed an intricate web of relations among different suspected criminals, government officials and the police force. When all the pieces of information are put together, the following picture emerges. The main income of the PKK is drug money and extortion. ${ }^{5}$ For a time, the Kurdish mafia in Istanbul and in Europe acted as the marketing agents. The gambling business, again owned by the Kurdish drug-lords, was used for money laundering. In 1993, the Turkish government, seeking to curb the PKK's revenues, hired some extreme Turkish nationalist outlaws to eliminate the Kurdish mafia in Istanbul. The task was accomplished successfully.

Then the nationalist mafia took over the drug business. The new dealers failed to market the drugs in Europe. This resulted in an attempt to target the domestic market and drug prices dropped drastically there. This coincided with an alarming increase in drug-related deaths among Turkish youth. The claim was made recently that Turkey had become a major drug supplier to the West, providing $80 \%$ of drugs consumed there. ${ }^{6}$

The Kurdish conflict has also created other power centers. For example, progovernment feudal tribes in the southeast region which were armed by the state to fight against the PKK have become small military powers in themselves. The Bucak tribe currently commands 10,000 armed men. There is evidence that some village guards ${ }^{7}$ and other government appointees have been engaged in drug trafficking and arms sales. In Yuksekova a group com- 
posed of members of the special team, village guards and the police committed various illegal activities, representing themselves as PKK members. To date, 3,687 village guards - out of 60,000 - have been dismissed from their jobs because of illegal activities.

Another issue is the rehabilitation problem of the homecoming soldiers. It is reported that $27.8 \%$ of the soldiers who were referred to a major military hospital with psychological complaints were diagnosed as suffering from the Vietnam Syndrome. The recorded ratio for US soldiers during the Vietnam War was $27 \%{ }^{8}$

The Kurdish conflict is one of Turkey's major challenges in the post-Cold War period. The dimensions of this severe problem have several aspects. The first is economic. Over one third of the annual budget of the central government is spent on the conflict. Hence it represents a major factor behind high budget deficits (and the associated inflation rate of around 80\%). Along with interest expenditures on public debt, military expenditures have crowded out expenditures on the social sector such as health and education as well as public investment. Rising unemployment and a decrease in social services are some of the by-products of the worsening economic situation. This, in turn, has had a detrimental effect on the social fabric and contributed to the strengthening of radical Islam, ethnic polarization, and nationalism. Another related aspect is the refugee problem. People who had to leave the region pose important social and economic problems in the metropolitan areas.

The second aspect is democracy. The measures taken to control the conflict act to impede the development of democracy in Turkey. Missing persons, torture, and forced migration are the points most often mentioned in the human rights reports of both Turkish and international nongovernmental organizations. Similarly, democratization packages seeking the abolition of articles in the Constitution which constrain freedom of thought and expression - such as article 8 - and certain institutions such as the state security courts have failed to materialize. The complex web of relations among suspected criminals, government officials and the police force proves the existence of state-privileged illegal groups in politics, raising doubts about whether the rule of law exists in Turkey. The human rights record is an issue in Turkey's international relations as well. It has featured prominently in international discussions about the Cyprus problem and negotiations for full membership in the European Union.

The third is the international aspect. The Kurdish issue has become a constraint on the formulation of Turkish foreign policies. Post-Cold War Turkish foreign policy is static, defensive, and reactive, and avoids taking risks. AntiPKK lobbying and containing the PKK's threat to Turkey's security have become the main, if not the only, focus of foreign policy. This prevents the generation of multilateral cooperative strategies which might enhance Turkey's interests in the long run. Turkey's relations with its neighbors - Syria, Iraq, Iran, Armenia, Russia, Greece - are mostly governed by the level of support these countries provide to the PKK. Accordingly, the solution of the 
water conflict between Turkey and Syria is connected to the Syrian-PKK relationship. Turkey's relations with Iraq are heavily influenced by the political status of northern Iraq, and, indirectly, by the status of the PKK in the region. Armenia, Russia, and Greece, it is often claimed, are all providing supporting for the separatist organization. The Kurdish issue put constraints on Turkey in the formulation of its policies towards Cyprus and Turkish minorities in Greece and Bulgaria. ${ }^{9}$

\section{TURKISH POLITICAL ACTORS: CONTEXTS AND PERCEPTIONS}

In this section the attitudes of different Turkish political actors - the armed forces, the President of the Republic, political parties, and interest groups towards the sources of the Kurdish conflict are examined and identified. ${ }^{10}$ Their views are as expressed in the Turkish written and broadcast media.

(1) Turkish Armed Forces: This is a struggle against a terrorist group (PKK) and its international supporters who desire to destabilize and weaken the political, economic, and territorial integrity of Turkey. The armed forces draw a parallel between the current situation and the Turkish War of Independence (1919-23), and want to show the same bravery against foreign enemies. Such suggestions as opening communication channels with the other party, or holding indirect talks with the PKK, are automatically considered to be an assault on the involvement and raison d'etre of the Turkish army.

The reaction of the army to a peaceful solution to the conflict can be summarized as follows: The armed struggle against the PKK has been going on for the past 13 years. Attempts to establish a dialogue or advocate a political solution will impede these efforts and cannot justify the casualties suffered during this period. The use of the Kurdish language in private and on national television is against the existing constitution, and to grant any such official right is the first step to separatism. Indeed, the army sees any constitutional right conceded to the Kurds as the first concession on the road to separation. Constitutional rights will lead first to claims for autonomy, later for federation and finally separation. High-ranking soldiers in the field, on the other hand, claim that their responsibility is limited to the military aspect of the issue. They believe that it is the job of the civil authority to deal with the other aspects of this conflict such as the improvement of living conditions in Kurdish areas ${ }^{11}$ Recently the military invited the private sector to invest in the region, on the grounds that without such local-level investment, the PKK cannot be defeated.

(2) The President: In 1991, Suleyman Demirel, prime minister in the coalition government, acknowledged the existence of a 'Kurdish reality' in Turkey in a speech in Diyarbakir. ${ }^{12}$ In 1993, however, he declared that extending cultural rights to the Kurds would be a concession to terrorism. Unless terrorism comes to an end, cultural rights cannot be an item on the agenda. After Demirel became president in 1994, he, for the first time, pronounced the idea of 'Consti- 
tutional Citizenship', that is, citizenship based on constitutional rights and not on nationality. He also talked about the idea of 'transformation from a nation state to a human-rights state'. By contrast, in 1996, Demirel strongly opposed the idea of having a dialogue with the PKK through an intermediary by saying that the state cannot negotiate with terrorists. According to some, Demirel is searching intellectually for a solution to the issue but shies away from taking initiatives because of the sensitive political climate. ${ }^{13}$

(3) Democratic Left Party (DSP): The DSP is a centre-left party and the minority partner in the current coalition government that came to power in June 1997. The party emphasizes the economic underdevelopment of the region and claims that the existing feudal structure has a negative affect on development. Underdevelopment makes the region vulnerable to separatist attempts, and neighboring countries take advantage of this. According to the DSP, the power vacuum in northern Iraq is another aggravating factor and has to be filled by the Turkish Army. A security system through a buffer zone must be constructed along the Iraqi border. The feudal structure should be demolished through public investments and land reform. ${ }^{14}$ The DSP does not recognize the cultural and ethnic dimensions of the problems.

(4) National Action Party (MHP): The MHP is an ultra-nationalist, right-wing party. It advocates that PKK terrorism is a conspiracy against Turkey engineered by external forces such as Greece, Armenia, and Syria whose aim is to destabilize Turkey and cause it to disintegrate. The Kurdish problem will stop if external support ends. Military measures are the only way to deal with this problem. The army is not well equipped to fight against terrorism, so special military forces will have to be created. ${ }^{15}$ According to the MHP, the Kurds have been their brothers for centuries. The party does not recognize a separate Kurdish ethnic identity. As regards the possibility of a political solution, the state cannot negotiate with terrorists, bandits, and criminals. Any political solution will lead to the questioning of the existing state system, which in turn will cause the disintegration of the state. Therefore, says the MHP, political solutions are out of the question. ${ }^{16}$

(5) Welfare Party (RP): The RP, the main Islamist party in Turkey, was in government as a senior coalition member from June 1996 to June 1997. In its election declaration in October 1991, it argued that there was not a southeastern problem but a problem of the regime, and it stressed Islam as a unifying factor. ${ }^{17}$ A recent declaration by Abdullah Gul, the former State Minister and a key political figure from the Welfare party, suggests that this view has not changed. In November 1996, Gul stated that 'Racist approaches to the conflict are wrong, and may result in a civil war. The problem can only be solved by relying on one common denominator; Muslim brotherhood. This is not only a remedy to the problems of southeastern Turkey but also to the relations in the larger area concerned, i.e. relations between Turkey, Syria, Iraq, and Iran. ${ }^{18}$

In his party's fourth convention in October 1993, Necmettin Erbakan, the RP's leader, said that the region was under pressure from the state. He made the 
following points: The power of the armed forces is increasing, and the warlike situation continues. The problem cannot be solved through the use of violence and indirect assimilation. Kurds and terrorism are two concepts that should be treated separately. The right to broadcast and educate in the Kurdish language should be granted. The state of emergency has to be abolished. ${ }^{9}$

(6) Motherland Party (ANAP): This is a center-right party, the majority partner in the current coalition government. ANAP supports the struggle to eliminate terrorism. On the other hand, it also claims that military action is not the only solution to the problem and should be complemented by economic and social measures. ANAP's 1995 election declaration made the following promises on the Kurdish issue: (a) the state of emergency imposed by the government in the southeast would be abolished; (b) the village guard system would be revised; (c) measures to enhance the right of self-expression would be taken; (d) reset tled people would receive compensation for their losses; and (e) economic and social development of the region would be encouraged.

(7) Republican People's Party (CHP): As a party of the centre-left, it also differentiates between terrorism and the Kurdish problem. It claims that the principle of the unitary state and Turkish as the official language should be preserved. The CHP considers the problem as one of democratization. Freedom of expression, the establishment of Kurdish TV, and other cultural institutions are measures that should complement military measures.

(8) True Path Party (DYP): For the DYP, a center-right party, the PKK is a terrorist organization and the conflict is a straggle between terrorists and the state. In its 1995 election declaration, the DYP announced a construction project and an action plan to improve the worsening economic conditions in the region. Among its specific suggestions were improvements in irrigation systems, and developing the textile, animal husbandry, and construction industries. ${ }^{20}$

(9) Worker's Party (IP): The IP, a leftist party, claims that the main reason behind the problem is the US interest in the region. The creation of a de facto Kurdish state in northern Iraq, after the Gulf War, is a direct result of US economic interest in the region. This problem cannot be solved without opposing the USA. Furthermore, a change in the Turkish Constitution is required: according to IP leader Dogu Perincek, the first sentence of the Amasya declaration of Kemal Ataturk states that 'Turkey is the homeland of the Turks and Kurds'. ${ }^{21}$

(10) Democratic Mass Party (DKP): The DKP, a newly established Kurdish party, was founded in January 1997 by a former CHP deputy, Serafettin Elci. It is a 'moderate' Kurdish party in terms of its distance from the PKK and its adoption of liberal policies and its view on Islam. The DKP's founders claim that their primary objective is to solve the Kurdish problem in Turkey. Reorganization of the state, recognition of the Kurdish identity, cultural rights for the Kurdish community, decentralization, and state reform are policies that DKP has in its party program. ${ }^{22}$

(11) Democratic Peace Party $(D B F)$ : This is another new political party mainly composed of the members of the Alawite ${ }^{23}$ sect of the population. According to 
this party, the main reason for the Kurdish conflict in Turkey is the imposition of a single identity by the state and its failure in economic and social affairs. Developmental gaps among regions, especially poor economic and social conditions in the southeast are related important causes of the conflict. Democratization and implementation of economic and social measures which will help abolish the tribal (feudal) relationships and decrease interregional developmental discrepancies have been suggested for the resolution of this conflict. ${ }^{24}$

(12) MUSIAD (Independent Industrialists' and Businessmen's Association): MUSIAD is a business association composed of Islamist industrialists and businessmen. Erol Yarar, the President of MUSIAD, emphasizes the role of Syria in the Kurdish conflict in Turkey, and argues that 'The water problem between Syria and Turkey seems to be the key issue in the conflict. With an agreement on the water problem with Syria we can eliminate the PKK in six months. ${ }^{25}$

(13) TUSIAD (Turkish Industrialists and Businessmens' Association): TUSIAD is one of the most influential interest groups in Turkey. Prominent businessmen and industrialists in TUSIAD note the need to extend cultural rights to the Kurds, and draw a line between terrorism and the need for accommodating the Kurdish identity. ${ }^{26}$ Can Paker, a former member of TUSIAD's executive board, claims that Turkey's international credibility cannot be regained until the Kurdish and Cyprus problems have been solved. According to Paker, the war consumes an extraordinary amount of wealth. Only the gray economy, which could be almost three times of the size of the state budget, has prevented economic disasters.

(14) TUGIAT (Turkish Young Businessmen's Association): Murat Bedik, the president of the TUGIAT executive board, focuses on the economic and social development of the southeast, and states that' the worsening economic condi tions in the southeast region and the spread of terrorism are two related phenomena. Therefore, top priority should be given to the economic and social development of the region. Development projects should be prepared and implemented with the collaboration of the locals. The role of the NGOs is crucial in this process. They are the primary agents who will establish a dialogue between the locals and the establishment. If their voices are heard, they will serve as a means to create a critical mass on the issue. ${ }^{27}$

\section{CONFLICT INTERVENTION/MANAGEMENT ATTEMPTS REVIEWED}

Different attempts at intervention have been made by the business community, peace activists, and NGOs. Various research reports have been prepared by different interest groups on aspects of the conflict. Examples include studies sponsored by Turkish Union of Chambers, ${ }^{28}$ the Union of the Turkish Metal Workers, the Center for Political Psychology of the Prime Ministry, and by Sakip Sabanci, a prominent businessman and public figure. TUSIAD has repeatedly warned the government about the need for a peaceful solution to the conflict. On 
the initiative of the Istanbul Chamber of Commerce, 'East Holding' has been established with the participation of different prominent business people - from and outside the region - with the aim of helping the economic development of the eastern and southeastern region. A 'one million votes for peace' campaign was launched by a group of peace activists. The 'Peace Express', a trip by train from Istanbul to Diyarbakir, and the film documenting this venture, 'Cinema for Peace', are other civic attempts by the Human Rights Association. 'Saturday Mothers', the relatives of missing people, meet every Saturday in Istanbul to make their voices heard. 'Search conferences' on the Kurdish problem, by the White Point Foundation, have been arranged with broad participation by intellectuals of both Turkish and Kurdish origin. The Turkish branch of the Helsinki Citizens Assembly conducts projects in the region with local officials, on community rebuilding and governance issues. The Foundation for the Research of Societal Problems (TOSAV) is a recent NGO which aims at constructive dialogue between the Turkish and Kurdish communities.

At the governmental level there have been different attempts to deal with this problem. ${ }^{29}$ The pioneer was Turgut Ozal, the late prime minister and President of the Republic, who was the first to launch the 'melting pot' idea in the Turkish context. On 20 August 1989, Ozal, then prime minister, in a meeting in Istanbul with the members of the US Helsinki Commission, claimed that one of his grandmothers was Kurdish. ${ }^{30}$ Before his death in 1993 he said that he was open to discussion of the idea of a federation.

Recent governments have come to power with differing agendas for dealing with the Kurdish problem: Demirel of the DYP in 1989; followed by Ciller, also DYP, in the summer of 1993; then Yilmaz of ANAP; and the Welfare-True Path coalition in June 1996-97. All these prime ministers began their political terms with mild positions on the Kurdish problem but later either became hardliners or changed their position as their term in office progressed. ${ }^{31}$

In the summer of 1996, the mediation attempt to solve the Kurdish problem in Turkey by the Welfare Party and the True Path Party coalition government illustrates the dynamics of this transition. After Turgut Ozal's death, Erbakan's initiative on the problem was one of the more radical efforts. For the first time, in August 1996, there was an effort at active mediation. Erbakan, former Islamist prime minister of Turkey, used an Islamic writer and NGO spokesperson, Ismail Nacar from the Committee for Peace, Fraternity, and Solidarity, in the mediation effort described below.

\subsection{The Background to the Mediation Attempt}

After Erbakan had become prime minister in June 1996, Zubeyir Aydar, president of the executive committee of the Kurdish parliament-in-exile, called Nacar and proposed that he mediate in this dispute. Nacar contacted Erbakan through Welfare Party deputies and met with him on 27 July 1996. At this meeting Erbakan said his primary mission was to stop the bloodshed and end this 
conflict. Erbakan appointed Fethullah Erbas, the Welfare Party deputy for Van in eastern Turkey, to conduct negotiations along with Nacar. This development was interpreted as bestowing Erbakan's blessing on direct talks with the PKK. Three days later, Nacar and Fethullah Erbas paid a visit to the imprisoned Kurdish deputies from the Democracy Party (DEP) with special permission from the Ministry of Justice. Nacar also contacted Abdullah Ocalan, the head of the PKK, and the president of the Kurdish parliament-in-exile. These developments were leaked to the press and opened a public debate on the issue. The CHP, DSP, MHP, ANAP were all extremely critical, on the principle that the state should not negotiate with terrorists. Mixed signals came from the coalition partner DYP, which found itself in the dilemma of having been hawkish by reputation in the past but was now in government together with the Welfare Party.

In the meantime, Welfare Party deputy Erbas tried to convince the leaders about the preconditions and proposals for peace. His proposals to the Turkish government included: the release of the arrested Kurdish deputies; partial amnesty for other prisoners; Kurdish education in private schools; and Kurdish broadcasting at certain hours on the state television. Erbas' suggestions to the PKK were: a ceasefire, an end to border violations by the armed forces, and the release of captured Turkish soldiers.

This caused an immediate reaction from the National Security Council and President Demirel. The army openly stated that it was not happy with the mediation effort. Later, the DYP also adopted a clear hardliner position. On the basis of these reactions from the opposition parties and the military establishment, the mediators had to declare that, in their efforts, they were representing themselves and not the government or the Welfare Party. Even Prime Minister Erbakan now declared that the state could not negotiate with terrorists. However, a few days later, the mediation team became involved in a project to secure the release of Turkish soldiers held by the PKK, and visited PKK camps where these soldiers were being held. A representative from the OSCE Kurdestan Human Rights Project acted as go-between with the PKK. However, the PKK did not release the soldiers, and demanded that there be an official representative from the government if any deal was to be struck. This in turn caused strong reactions from the opposition parties, who demanded Erbas' resignation. In December, however, six soldiers were freed by the PKK.

The heated public debate and criticism arising from these two attempts at mediation were broadly based on the following arguments: (1) The state cannot negotiate with terrorists; (2) These efforts were simply vote-gathering populist attempts made by the Welfare Party; (3) The choice of mediators was questionable (because of their previous relations with the PKK and their Islamist background); (4) The design of the intervention process was inadequate (public, not private; the media were manipulated, etc.) As a result of all this criticism the Welfare Party stepped back and kept a low profile about the issue. At the Welfare Party convention, party leader and prime minister Necmettin Erbakan was careful not to mention the Kurdish problem at all. 


\section{PASSING OBSERVATIONS}

a) The Kurdish problem is not viewed as a supra-party issue in Turkish domestic politics. The 1996 mediation attempt was treated by the opposition parties along opposition lines, secularists opposing a ruling Islamist party.

b) The nature of 'non-military' solutions is not clear in the minds of the main actors. The term is generally used to refer to approaches that focus on improving the economic and social conditions of the region. Direct means to solve the problem, such as mediation and negotiation, are not welcomed.

c) There is also confusion in the identification of the deeper causes of the problem. The Democratic Left Party bases its argument on the feudal structure of the region. The business community sees the problem as one of underdevelopment. The hawks, such as DYP and MHP, see foreign plots as a main factor; to the military and the hawks, the problem is also one of terrorism. Lack of democracy, an identity problem and psychological factors are cited by the Kurdish and Alawite parties. One element which is common to all is the perception that economic reform in the region is imperative.

d) There is a problem in finding a legitimate counterpart for mediation and negotiations. Turkey has one, newly established, political party based on Kurdish ethnic identity: this is the DKP, which is not currently represented in the National Assembly. Most deputies of Kurdish origin are scattered among different mainstream political parties. An attempt to form a distinct Kurdish political party was made in 1991, and 22 deputies from the pro-Kurdish People's Labor Party (HEP) were elected. In 1993, the HEP was outlawed by the Constitutional Court on the grounds that the integrity and the unity of Turkey had been violated. It successors, the Freedom and Democracy Party (OZDEP) and the DEP, were also banned by the Constitutional Court. These developments have caused a major problem in finding a legitimate Kurdish counterpart party in the parliamentary system. 'Dialogue with whom?' is the major dilemma that the advocates of a non-military solution face. Moreover, the ruling elite assumes that the 'other' party or a possible 'third' party should have a 'pure' background, i.e., a lily-white record on the conflict. In such a prolonged conflict this is surely an impractical and unrealistic expectation.

e) The ruling elite, by adopting either a hardline attitude or no attitude at all, has lost its leverage for generating a political solution. Mainstream political actors are faced with two dilemmas. One is how to disassociate themselves from the already-committed hardline positions without losing face and votes (a dilemma mainly experienced by ANAP and DYP); another is how to initiate a peace attempt without becoming the black sheep of the system (a dilemma of socialist or left parties). Over-nationalistic policies on the issue impede collective action for finding a solution.

The inability to generate a viable solution is further reinforced by the current general incapacity of the Turkish polity to produce public policy on almost any of the serious economic, social, and international problems facing 
the country. It is evident that politics in general has been reduced to a game of capturing public resources and then redistributing them through legal and illegal means. There is an almost complete absence of meaningful debate among the political elite. In rare cases when policy proposals are made, political debate immediately disregards the substantive elements of such proposals, and degenerates into shallow attacks. In effect, policy debates are subverted, manipulated, and transformed into an instrument for debasing and condemning opponents.

f) The fact that the political system cannot generate a viable process for a political solution, renders by default the military solution adopted by the army the only available solution. The recent collective opposition by the secular front (mainstream left and right) has de facto legitimized the military alternative.

g) Improvement of the Kurdish region's economic and social living conditions is viewed as the mechanism to solve the conflict peacefully. This is a necessary condition for dealing with the problem, but it remains to be seen whether economic investment in the region can become a sufficient condition to stop the war.

h) There is an irony as regards the economic cost of the Kurdish conflict. Drug trafficking, as a by-product of the conflict, has been pumping considerable sums into the system. This has turned out to be one of the factors which prevent a total collapse of the economy. The gray economy has also generated interest groups who have a stake in the conflict's continuation.

\section{CONDITIONS FOR ENDING THE CONFLICT}

Literature on conflict termination emphasizes several variables that impede or facilitate such a process. ${ }^{32}$ The main variables are: (a) a major change in the power configuration, such as a major offensive; (b) a hurting stalemate, one that imposes increasing costs to the parties and is also associated with a low probability of success and a high probability of a future disaster; (c) a change in leadership producing a new leader who can break with traditional stands on the conflict; (d) increasing opposition by pressure groups and opposition parties; (e) the emergence of a prospect for a new international alliance; (f) the presence or absence of foreign support; and (g) a major change in the international climate.

In the Kurdish conflict it seems difficult to expect any major change in the relative power configurations of the Turkish Army and the PKK. Despite statements by the Army on an almost annual basis that by 'the end of the year' the PKK will vanish, this has not yet occurred. At present, the conflict is at a stalemate. Despite the heavy cost to the Turkish side, the mentality of 'too much has been invested to quit' dominates the logic of decision-makers. There is still the belief that in conjunction with military measures, economic and social investments will end the problem. From the PKK's point of view, time would 
seem to be working for them: they are increasingly able to make their voice heard internationally and have become better and better organized in Europe and the USA. Therefore, although a stalemate exists, the parties to the conflict still entertain high hopes for success.

The previous change in the government did not have a serious impact on termination of the conflict, mainly because the Welfare Party had only $20 \%$ of the total vote. The lack of political power is an impeding factor in executing policies, given the strong reactions of the opposition parties and the army. In June 1997, a new ANAP/DSP coalition government under Prime Minister Mesut Yilmaz, the head of the Motherland Party, was formed. Improvement of the economic conditions of the region is the main priority of this government as regards the Kurdish problem. Issues such as cultural or ethnic rights are not mentioned in the government's program. This was interpreted as reflecting the strong influence of the coalition partner Bulent Ecevit, a former prime minister and the leader of Democratic Left Party, who claims that the essence of the Kurdish problem is economic. It would be unlikely to expect a drastic attempt by this new government to seek a solution to the problem, since its formation was the product of a collective effort of the secularist mainstream political parties and the military against the ruling Islamist party.

The performance of the new government is not expected to differ sharply from the existing patterns of political behavior or challenge the political culture under which Turkish political institutions are shaped. Political parties have become vehicles for nurturing clients and redistributing profits. Less emphasis has been put on a national vision, skills in statecraft, and problem solving. 'The national assembly becomes less a forum of debate, deliberation and policy making, and more an organization of individuals who are under constant pressure to repay their liabilities to narrowly defined constituencies. ${ }^{33}$

As for the role of public opinion, the conflict has caused an increase in nationalist sentiments as casualties increased. In addition, the relationship between economic hardship and the conflict is not apparent to the average citizen, mainly because the media have acted as a party in the psychological warfare between the government forces and the PKK, rather than providing objective accounts of the current situation. That is why there is no effective opposition from below to stop the conflict. On the other hand, as noted before, there are various NGOs which are active. Since the political apparatus is inadequate for generating a viable solution to the conflict, increasing pressure from below through NGOs and interest groups would seem to be the only way to make a difference.

As for the effect of a new international alliance, in similar conflicts, promises of membership in an international organization, such as the IMF, the World Bank, NATO, or the EU, have often been used by the mediators as an incentive to end conflicts. Turkey's joining the European Union is under negotiation, but immediate membership is not likely in the short term. It would seem that membership in a new alliance or organization does not constitute an incentive and cannot 
impose standards or conditions for ending the conflict. In fact, as the conflict persists, it becomes increasingly more difficult for Turkey to be accepted as a full member of the EU precisely because of its record on democratization, as highlighted by the conflict, and the associated human rights problems.

\section{CONCLUSIONS}

Given the perspectives of the official mainstream Turkish actors, the Kurdish conflict in Turkey is not yet ripe for resolution. One reason is that the Turkish political actors share different views about its origins. Second, officials do not feel that all alternatives have been fully explored. Third, economic hardships have not caused a total breakdown of the economy. Finally, national identity crises which emerged during the period of the RP/DYP government have resulted in the over-domination of a Kemalist nationalist ideology based on monocultural understanding of nationhood and the principle of protecting the unity of the existing Turkish state.

The official Turkish actors are extremely sensitive to any outside conflict-resolution intervention, regarding such attempts as violations of Turkey's sovereignty or as parts of international plots to weaken Turkey. Any direct intervention by outsiders especially without due consideration as to timing, target, and content - is likely to have a negative impact on the domestic peacemaking activities, as well as on the improvement of the Turkish democracy in general. At this stage, a productive policy could be to empower the domestic NGOs who are interested in resolution of the conflict, combined with wide-ranging efforts to acquaint the political actors with skills and training in conflict resolution.

\section{NOTES AND REFERENCES}

* Dr Nimet Beriker-Atiyas is assistant professor in the Department of International Relations of Bilkent University in Ankara. She received her doctorate from the Institute for Conflict Analysis and Resolution at George Mason University in Fairfax, Virginia, USA.

1 For the history of the conflict, see Henri Barkey, 'Turkey's Kurdish Dilemma', Survival, vol. 35, no. 4,1993, pp. 51-70; Michael Gunter, 'The Kurdish Problem in Turkey', Middle East Journal, vol. 42, no. 3,1988, pp. 389-406; Omer Faruk Genckaya,'The Kurdish Issue in Turkish PoliticsAn Overview', Islamic World Review, vol. 1, no. 3,1996, pp. 94-101.

2 Milliyet, 17 August 1996. For the details of the changing positions of the PKK see Kemal Kirisci \& M. Winrow, The Kurdish Question and Turkey: An Example of Trans-State Ethnic Conflict (London: Frank Cass, 1997).

3 Hasan Cemal, Sabah, 28 July 1996; Dogu Ergil, Daily News, 28 July 1997; Kirisci \& Winrow, The Kurdish Question.

4 Radikal, 5 December 1996.

5 Nur Bilge Criss/The Nature of PKK Terrorism in Turkey', Studies in Conflict and Terrorism, vol. 18,1995, pp. 17-37; Yalcin Dogan, Milliyet, ll'November 1996; Sabah, 23 February, 1997.

6 Yeni Yuzyil, 16 October 1996. 
7 The village guard system is a local defence force recruited, armed, and paid by the central authority. It consists of local villagers and is distinct from the army and the police.

8 Milliyet, 11 December, 1996.

9 For a detailed account of the international dimensions of the Kurdish conflict, see Kirisci \& Winrow The Kurdish Question.

10 The underlying assumption of this effort is twofold. One is the belief that in any conflict situation a major first step of the third parties - researchers, activists, policymakers, and conflict resolvers - is to clarify the way in which parties to the conflict identify the issues. This step is seen as crucial to carrying out a sound analysis of the conflict and establishing an ethical basis to any possible intervention. Second, it is assumed that one of the major obstacles to a peaceful solution to the conflict stems from the fact that the parties have different metaphors in perceiving, understanding, and interpreting similar events.

11 Hasan Cemal, Sabah, 28 July 1996.

12 According to this author, this was an important turning-point in the history of the conflict and it represented the end of a policy of denial as regards the Kurdish problem in Turkey.

13 Sedat Ergin, Hurriyet, 5 November 1996.

14 Bulent Ecevit, in a TV program broadcast by ATV, Siyaset Meydani 'The South East', 24 December 1994.

15 From the official election declaration of MHP on the eve of Turkey's general elections of 24 December 1995.

16 Yasemin Ersolak, "The Kurdish Conflict', unpublished paper (1994), Bilkent University, Department of International Relations.

17 Ibid.

18 Milliyet, 4 November 1996.

19 Radikal, 16 October 1996.

20 DYP Election declaration immediately prior to the general election of 24 December 1995.

21 Dogu Perincek, in a TV program broadcast by ATV, Siyaset Meydani 'The South East', 24 December 1994.

22 Milliyet, 3-4 January 1997, and Yeni Yuzyil, 30 January 1997.

23 Alawites are Anatolian Shiites; the majoiry of the Turkish population is Sunni.

24 From the action program of the Democratic Peace Movement, 'Peace Project: Principles and Goals'.

25 Milliyet, 24 July 1996.

26 See Kirisci \& Winrow, The Kurdish Question (note 2 above).

27 Interview with Murat Gedik, Milliyet, 3 September 1996.

28 See Meltem Muftiiler-Bac/Negotiating Kurdish Separatism in Turkey,' in Marc Howard Ross \& Jay Rothmans, eds., Theory and Practice in Ethnic Conflict Management: Conceptualizing Success and Failure (London and New York, Macmillan, forthcoming).

29 See Genckaya 1996 and Barkey 1993.

30 Ufuk Guldemir, Texas Malatya (Istanbul: Tekin Yayinevi, 1992), p. 407.

31 For a detailed account of the events see Henri Barkey \& Graham Fuller, 'Turkey's Kurdish Question: Critical Turning Points and Missed Opportunities', Middle East Journal, vol. 51, no. 1,1997, pp. 59-79.

32 Christopher Mitchell, Cutting Losses: Reflections on Appropriate Timing. Working Paper, George Mason University, no. 9, March 1996.

33 Izak Atiyas, The Effect of the State's Presence in the Economy on Politics: Notes on the Reform of the State, Paper presented at the 5th National Conference on Quality: Total Quality Management and Quality in Politics, 13-14 November 1996, Istanbul. 